\title{
KERCERNAAN IN VITRO BAHAN KERING DAN BAHAN ORGANIK SERTA PROTEIN RANSUM BERBASIS PAKAN FERMENTASI
}

\author{
Aang Baitul Mizan', Andi Murlina Tasse', Deki Zulkarnaen² \\ ${ }^{1)}$ Alumnus Fakultas Peternakan UHO \\ ${ }^{2)}$ Staf Pengajar Fakultas Peternakan UHO \\ "e-mail : andimurlinatasse@gmail.com
}

\begin{abstract}
ABSTRAK
Penelitian ini bertujuan mengevaluasi kelayakan penggunaan ransum berbasis pakan fermentasi untuk ternak ruminansia berdasarkan kecernaan bahan kering dan bahan orgaik serta protein secara In Vitro. Penelitian ini dilaksanakan selama empat minggu di Laboratorium Ilmu Nutrisi dan Makanan Ternak Fakultas Peternakan Universitas Haluoleo, Kendari. Perlakuan yang dicobakan adalah $\mathrm{R} 0=$ ransum berbasis pakan non fermentasi (kontrol), $\mathrm{R} 1=$ ransum berbasis dedak padi fermentasi $40 \%, \mathrm{R} 2=$ ransum berbasis dedak padi fermentasi $45 \%, \mathrm{R} 3=$ ransum berbasis dedak padi fermentasi $50 \%, \mathrm{R} 4=$ ransum berbasis dedak padi fermentasi $55 \%, \mathrm{R} 5=$ ransum berbasis dedak padi fermentasi $60 \%$. Rancangan percobaan yang digunakan rancangan acak kelompok (RAK) dengan 5 perlakuan dan 4 kelompok. Hasil analisis ragam menunjukkan kecernaan bahan kering ransum berbasi dedak padi fermentasi $40 \%, 45 \%$, dan $60 \%$ lebih tinggi dibanding dengan ransum berbasis pakan non fermentasi (94,17\%; 90,98\% dan 91,04\% dibanding dengan 88,60\%). Sebaliknya, ransum berbasis dedak padi fermentasi $50 \%$ dan 55\% lebih rendah dibanding dengan ransum berbasis pakan non fermentasi $(80,90 \%$ dan $80,89 \%$ dibanding dengan $88,60 \%)$. Kecernaan bahan organik ransum berbasis pakan non fermentasi lebih rendah dibanding dengan ransum berbasis dedak padi fermentasi 40\%, 45\%, 50\%, 55\% dan 60\% (62,58 \% dibanding dengan 90,32 \%, 90,55\%, 90,78\%, $91,15 \%$ dan $90,41 \%$ ). Sebaliknya kecernaan bahan organik ransum berbasis dedak padi fermentasi $55 \%$ lebih tinggi dibanding dengan ransum berbasis dedak padi fermentasi 40\%, 45\%, 50\%, 60\% dan kontrol (91,41\% dibanding dengan $90,32 \%, 90,55 \%, 90,78 \%, 90,41 \%$ dan $62,58 \%)$. Konsentrasi amonia ransum berbasis dedak padi fermentasi $40 \%, 45 \%, 50 \%, 55 \%$ dan $60 \%$ lebih tinggi dibanding dengan ransum berbasis pakan non fermentasi $(8,20 \mathrm{mM}, 5,40 \mathrm{mM}, 8,67 \mathrm{mM}, 7,22 \mathrm{mM}$ dan 7,42 $\mathrm{mM}$ dibanding dengan 3,20 mM). Kesimpulan bahwa ransum berbasis dedak padi fermentasi $40 \%$ hingga $60 \%$ layak digunakan untuk pakan ternak ruminansia.
\end{abstract}

Kata kunci: Pakan Fermentasi, Kecernaan Bahan Kering, Kecernaan Bahan Organik, Amonia.

\begin{abstract}
This study has conducted four weeks in Laboratory of Animal Nutrition Department of Animal Science, Faculty of Animal Science, Haluoleo University, Kendari. The treatments R0 = rations based feed's non fermented, $\mathrm{R} 1=$ rations based $40 \%$ rice bran fermented $(\mathrm{RBF}), \mathrm{R} 2=$ rations based $45 \% \mathrm{RBF}, \mathrm{R} 3=$ rations based $50 \% \mathrm{RBF}, \mathrm{R} 4=$ rations based $55 \% \mathrm{RBF}, \mathrm{R} 5=$ rations based $60 \%$ RBF. The experimental design used a randomized block design (RBD) with 5 treatments and 4 groups. The results showed that dry matter digestibility (DMD) of R1, R2, R5 higher than R0 $(94,17 \%, 90,98 \%, 91,04 \%$ vs $88.60 \%)$. In contrast, DMD of R3 and R4 lower than R0 $(80,90 \%$ and $80,89 \%$ vs $88,60 \%)$. Organic matter digestibility (OMD) of R0 lower than R1, R2, R3, R4 and R5 ( $62,58 \%$ vs $90,32 \%, 90,55 \%, 90,78 \%, 91,15 \%$ and $90,41 \%)$. In contrast, OMD of R4 higher than R1, R2, R3, R5 and R0 (91,41\% vs 90,32\%, 90,55\%, 90,78\%, 90,41\% and 62,58\%). Ammonia (NH3) concentrations of R1, R2, R3, R4 and R5 higher than R0 $(8,20 \mathrm{mM}, 5,40 \mathrm{mM}, 8,67 \mathrm{mM}, 7,22 \mathrm{mM}$ and 7,42 $\mathrm{mM}$ vs 3,20 mM). The conclusion of this study was FBR based $40 \%, 45 \%, 50 \%, 55 \%$ and $60 \%$ RBF feasible to ruminant's feed.
\end{abstract}

Keywords : Feed's Fermented, Digestibility, Dry Matter, Organic Matter, Ammonia.

${ }^{*}$ Correspong authors 



\section{PENDAHULUAN}

Ransum berbasis pakan fermentasi merupakan ransum yang terdiri atas pakan yang telah difermentasi. Pakan yang sering digunakan sebagai komponen ransum diantaranya hasil samping pengolahan hasil pertanian (dedak padi), perkebunan (bungkil kelapa) dan perikanan (tepung ikan). Namun penggunaannya terkendala dengan kualitas yang rendah. Salah satu upaya untuk meningkatkan kualitas pakan dengan menggunakan enzim-enzim pencernaan melalui fermentasi. Salah satu sumber enzim yang dapat digunakan untuk fermentasi pakan adalah cairan rumen karena mengandung mikroba yang dapat menghasilkan enzim-enzim pencernaan diantaranya selulase, xilanase, amilase, pektinase, lipase, protease dan lain-lain. Proses fermentasi mikroba mampu memecah komponen yang komplek menjadi zat-zat yang lebih sederhana sehingga mudah dicerna oleh ternak, serta mensintesa berbagai vitamin yang komplek (Widayanti \& Widalestari, 1996).

In vitro merupakan salah satu cara yang digunakan untuk menentukan kecernaan bahan kering dan bahan organik serta protein dalam rumen. Cara ini sebagai tiruan proses pencernaan ternak ruminansia. Keunggulan in vitro diantaranya waktu yang dibutuhkan lebih singkat dan pelaksanaannya lebih mudah dibandingkan denga metode lain seperti in vivo atau in sacco.

Kecernaan bahan kering menunjukan proporsi bahan kering ransum yang dapat dicerna oleh mikroba dalam rumen. Sedangkan kecernaan bahan organik menunjukkan proporsi bahan organik yang dicerna oleh enzim pencernaan yang dihasilkan oleh mikroba rumen. Kecernaan protein menunjukkan proporsi protein kasar ransum yang dapat dicerna oleh enzim pencernaan yang dihasilkan oleh mikroba proteolitik dalam rumen, yang ditunjukkan oleh konsentrasi amonia (Tasse, 2011).

\section{MATERI DAN METODE}

\section{A. Waktu dan Tempat}

Penelitian ini dilaksanakan selama empat minggu di Laboratorium Ilmu Nutrisi dan Tanaman Makanan Ternak Jurusan Peternakan Fakultas Peternakan Universitas Haluoleo Kendari.

\section{B. Materi Penelitian}

Pakan yang digunakan dalam penelitian ini adalah dedak padi, ampas sagu, ikan rucah, bungkil kelapa dan cairan rumen. Ransum yang digunakan dalam penelitian ini disajikan pada Tabel 1.

$$
\begin{aligned}
\mathrm{R} 0= & \text { Ransum berbasis pakan non } \\
& \text { fermentasi (Control) } \\
\mathrm{R} 1= & \text { Ransum berbasis dedak padi } \\
& \text { fermentasi } 40 \% \\
\mathrm{R} 2 \quad= & \text { Ransum berbasis dedak padi } \\
& \text { fermentasi } 45 \% \\
\mathrm{R} 3 \quad= & \text { Ransum berbasis dedak padi } \\
& \text { fermentasi } 50 \% \\
\mathrm{R} 4 \quad= & \text { Ransum berbasis dedak padi } \\
& \text { fermentasi } 55 \% \\
\mathrm{R} 5 \quad & \text { Ransum berbasis dedak padi } \\
& \text { fermentasi } 60 \%
\end{aligned}
$$

Alat yang digunakan adalah timbangan analitik, oven, tanur, corong plastik, gelas ukur $100 \mathrm{ml}$ dan $1000 \mathrm{ml}$, hot plate, tabung reaksi, panci, termometer ruangan, kertas label, kantong plastik, dan pastula. 
Tabel 1. Susunan Ransum Penelitian

\begin{tabular}{lcccccc}
\hline \multicolumn{1}{c}{ Pakan } & $\begin{array}{c}\text { R0 } \\
(\boldsymbol{\%})\end{array}$ & $\begin{array}{c}\text { R1 } \\
(\boldsymbol{\%})\end{array}$ & $\begin{array}{c}\text { R2 } \\
(\mathbf{\%})\end{array}$ & $\begin{array}{c}\text { R3 } \\
(\boldsymbol{\%})\end{array}$ & $\begin{array}{c}\text { R4 } \\
(\boldsymbol{\%})\end{array}$ & $\begin{array}{c}\text { R25( } \\
\mathbf{\%})\end{array}$ \\
\hline Dedak padi & 40 & 0 & 0 & 0 & 0 & 0 \\
Ampas sagu & 30 & 0 & 0 & 0 & 0 & 0 \\
Ikan rucah & 20 & 0 & 0 & 0 & 0 & 0 \\
Dedak padi fermentasi & 0 & 40 & 45 & 50 & 55 & 60 \\
Ampas sagu fermentasi & 0 & 30 & 30 & 30 & 30 & 30 \\
Ikan rucah fermentasi & 0 & 20 & 15 & 10 & 5 & 5 \\
Bungkil kelapa & 10 & 10 & 10 & 10 & 10 & 5 \\
\hline
\end{tabular}

C. Prosedur Penelitian

Pembuatan Pakan Fermentasi

Pembuatan pakan fermentasi

dilakukan dengan cara pakan

dikeringkan/dijemur terlebih dahulu, selanjutnya pakan dimasukkan dalam wadah, ditambah cairan rumen dan diaduk hingga rata. Wadah yang berisi pakan dan cairan rumen ditutup rapat dan didiamkan pada suhu ruangan selama tiga hari. Setelah tiga hari, pakan dikeluarkan dari wadah dan dikeringkan. Selanjutnya pakan dihaluskan dan diformulasi menjadi ransum.

\section{Kecernaan BK dan BO secara In Vitro}

Pengukuran kecernaan bahan kering dan bahan organik dilakukan dengan menggunakan metode Tilley dan Terry (1963) dalam Tasse (2011), yang telah dimodifikasi. Sebanyak 1-2 gram ransum ditimbang, dimasukkan dalam tabung reaksi dan ditambah dengan larutan saliva buatan sebanyak $12 \mathrm{ml}$ pada suhu $39^{\circ} \mathrm{C}$ dan $\mathrm{pH}$ 6,5-6,9 dan $8 \mathrm{ml}$ cairan rumen. Setelah itu tabung reaksi ditutup dengan penutup karet dan difermentasi secara anaerob selama 3 jam pada suhu 60-70 ${ }^{0} \mathrm{C}$. Setelah fermentasi, campuran ransum, saliva buatan dan cairan rumen ditetesi larutan $\mathrm{HgCl}_{2}$ jenuh sebanyak 0,2 ml untuk mematikan mikroba lalu disimpan pada suhu ruangan hingga terbentuk endapan. Selanjutnya hasil fermentasi disaring dengan kertas saring Whatman no.41, filtrat dikeringkan dalam oven pada suhu $105^{\circ} \mathrm{C}$ selama 24 jam. Setelah kering, sampel ditimbang menggunakan timbangan digital lalu dimasukkan dalam tanur pada suhu $1000^{\circ} \mathrm{C}$ selama $4 \mathrm{jam}$. Abu yang terbentuk ditimbang menggunakan timbangan digital. Koefisien cerna BK dan BO dihitung dengan persamaan:

$$
\begin{aligned}
& \mathrm{KCBK}=\frac{\mathrm{BK} \text { awal }-(\mathrm{BK} \text { reside }-\mathrm{BK} \text { blanko })}{\mathrm{BK} \text { awal }} \times 100 \% \\
& \mathrm{KCBO}=\frac{\mathrm{BO} \text { awal }-(\mathrm{BO} \text { residu }-\mathrm{BOO} \text { blanko })}{\mathrm{BO} \text { awal }} \times 100 \%
\end{aligned}
$$

Keterangan $; \mathrm{BK}=$ Bahan Kering
$\mathrm{BO}=$ Bahan Organik

\section{Pengukuran konsentrasi amonia $\left(\mathrm{NH}_{3}\right)$}

Kadar amonia ditentukan dengan teknik Mikrodifusi Conway (General Laboratory Procedure, 1966) dalam Tasse (2011), yang telah dimodifikasi. Sebanyak $1 \mathrm{ml}$ supernatan hasil inkubasin in vitro dimasukkan dalam tabung dan ditambah 1 ml larutan $\mathrm{Na}_{2} \mathrm{CO}_{3}$ jenuh dan asam borat berindikator bromkresol blue lalu tabung ditutup dan digoyang-goyang/dikocok sampai semua bahan tercampur. Selanjutnya, larutan dibiarkan pada suhu kamar selama 24 jam. Amonia yang terikat dengan asam borat dititrasi dengan $\mathrm{H}_{2} \mathrm{SO}_{4}$ $0,005 \mathrm{~N}$ sampai warna berubah dari biru menjadi merah muda atau bening. Kadar $\mathrm{NH}_{3}$ dihitung dengan rumus:

$\mathrm{N}-\mathrm{NH}_{3}=\left(\mathrm{ml}\right.$ titrasi $\left.\times \mathrm{N} \mathrm{H}_{2} \mathrm{SO}_{4} \times 1000\right)$ $\mathrm{mM}$. 


\section{Rancangan Penelitian}

Rancangan penelitian yang digunakan adalah rancanga acak kelompok dengan 5 perlakuan dan 4 kelompok (RAK 5x4). Model matematika mengacu pada Steel dan Torrie (1991) sebagai berikut:

$$
\mathbf{Y}_{\mathrm{ij}}=\boldsymbol{\mu}+\boldsymbol{\alpha}_{\mathrm{i}}+\boldsymbol{\beta}_{\mathrm{i}}+\varepsilon_{\mathrm{ij}}
$$

Dengan:

$\mathrm{Y}_{\mathrm{ij}}=$ Pengamatan pada kelompok ke-i $(\mathrm{i}=$ $1,2,3,4)$ dan perlakuan ke-j $(\mathrm{j}=1$, $2,3,4,5$ )

$\mu=$ Rataan umum

$\alpha_{\mathrm{i}}=$ Pengaruh kelompok ke-i $(\mathrm{i}=1,2,3,4)$

$\beta_{\mathrm{i}}=$ Pengaruh perlakuan ke-j $(\mathrm{j}=1,2,3,4$, )

$\varepsilon_{\mathrm{ij}}=$ Pengaruh galat kelompok ke-i dan perlakuan ke-j

\section{Variabel Penelitian}

1) Bobot Air (g) = bobot awal (sebelum oven, g) - bobot akhir (setelah oven,g)

2) Kadar Air $(\%)=$ bobot air/bobot awal x $100 \%$

3) Bahan Kering $(\mathrm{BK}, \%)=100 \%$ - kadar air $(\%)$

4) Bobot $\mathrm{Abu}(\mathrm{g})=$ bobot sebelum tanur (g) - bobot setelah tanur (g)

5) Kadar Abu (\%) = bobot abu / bobot awal sebelum oven $\mathrm{x} 100 \%$
6) Bahan Organik $(\mathrm{BO}, \%)=$ bahan kering $(\%)$ - kadar abu (\%)

\section{F. Analisis Data}

Data yang diperoleh dianalisis dengan sidik ragam untuk mengetahui pengaruh perlakuan. Jika perlakuan berpengaruh nyata maka dilanjutkan dengan uji DUNCAN (Hanafiah, 2008).

\section{HASIL DAN PEMBAHASAN}

\section{A. Kecernaan Bahan Kering}

Kecernaan bahan kering in vitro menunjukkan proporsi bahan kering ransum yang dapat dicerna oleh mikroba rumen. Kecernaan bahan kering mampu menunjukkan kualitas pakan dan besarnya kemampuan ternak dalam memanfaatkan suatu jenis pakan. Kecernaan bahan kering yang tinggi pada ternak ruminansia menunjukkan tingginya zat nutrisi yang dicerna. Kecernaan bahan kering yang tinggi menunjukkan nutrisi yang dapat diabsorbsi juga tinggi. Rataan kecernaan bahan kering in vitro ransum berbasis dedak padi fermentasi dapat dilihat pada gambar 2 .

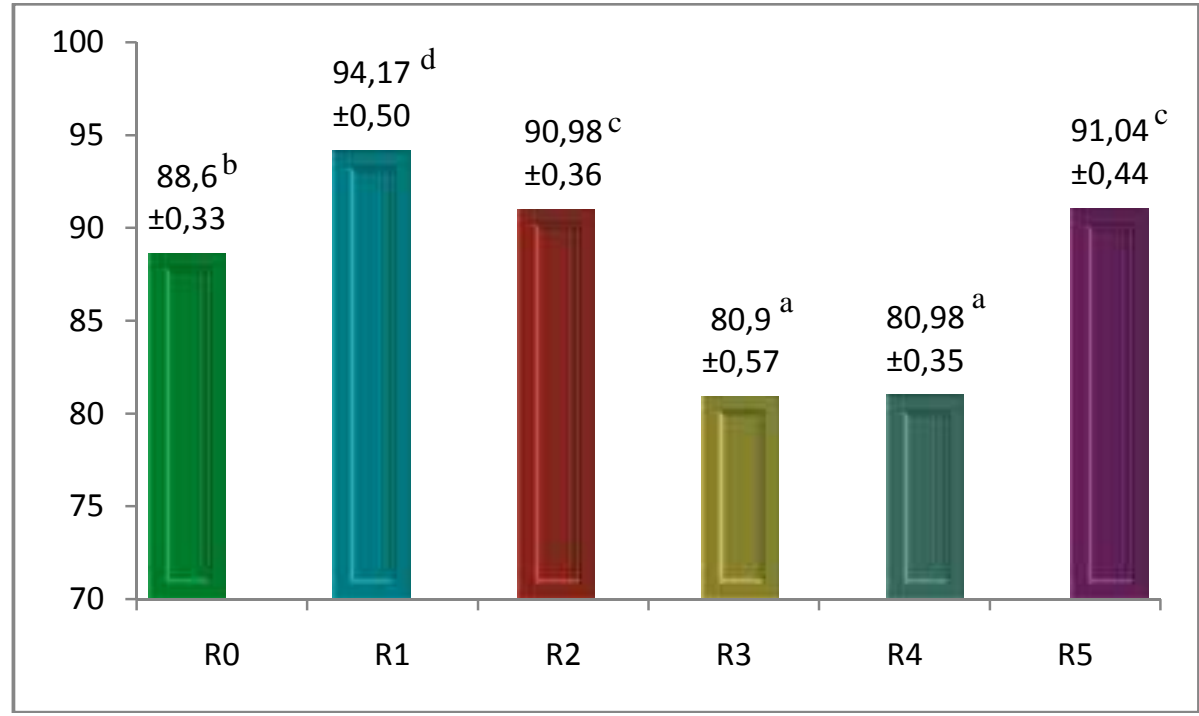

Keterangan; R0= Ransum berbasis pakan non fermentasi, R1= Ransum berbasis dedak padi fermentasi $40 \%$, $\mathrm{R} 2=$ ransum berbasis dedak padi fermentasi $45 \%, \mathrm{R} 3=$ Ransum berbasis dedak padi fermentasi $50 \%$, R4=Ransum berbasis dedak padi fermentasi 55\%, dan R5=Ransum berbasis dedak padi fermentasi $60 \%$.

Gambar 2. Grafik kecernaan bahan kering ransum berbasis dedak padi fermentasi 
Hasil analisis data menunjukkan kecernaan ransum berbasis dedak padi fermentasi dengan mikroorganisme cairan rumen sapi berpengaruh sangat nyata $(\mathrm{P}<0,01)$ terhadap kecernaan bahan kering ransum (Gambar 2). Ransum berbasis dedak padi fermentasi $40 \%$, $45 \%$, dan $60 \%$ lebih tinggi dibanding dengan ransum berbasis pakan non fermentasi $(94,17 \%, 90,98 \%$ dan $91,04 \%$ dibanding dengan 88,60\%). Sebaliknya, rataan ransum berbasis dedak padi fermentasi $50 \%$ dan $55 \%$ lebih rendah dibanding dengan ransum berbasis pakan non fermentasi $(80,90 \%$ dan $80,89 \%$ dibanding dengan $88,60 \%$ ).

Kecernaan bahan kering ransum berbasis dedak padi fermentasi $40 \%$ lebih tinggi dibanding dengan ransum berbasis dedak padi fermentasi $45 \%, 50 \%, 55 \%$ dan $60 \% \quad(94,17 \%$ dibading dengan $90,98 \%, 80,9 \%, 80,98 \%$ dan 91,04\%). Sama halnya kecernaan bahan kering ransum berbasis dedak padi fermentasi 45\% lebih tinggi dibanding dengan ransum berbasis dedak padi fermentasi $50 \%$, 55\% dan 60\% (80,9\% dibanding dengan $80,9 \%, 80,98 \%$ dan 91,04\%). Selanjutnya, rataan kecernaan bahan kering ransum berbasis dedak padi fermentasi $50 \%$ sama dengan kecernaan ransum berbasis dedak padi fermentasi $55 \%$, tetapi lebih rendah dibanding dengan kecernaan ransum berbasis dedak padi fermentasi $60 \%$. Demikian pula kecernaan bahan kering ransum berbasis dedak padi fermentasi 55\% lebih rendah dibanding dengan kecernaan ransum berbasis dedak padi fermentasi $60 \%$ (80,9\% dibanding dengan 91,04\%). Hal ini menunjukkan kemampuan optimal dari mikroba dalam cairan rumen untuk mendegradasi pakan, pada taraf $40 \%$ dedak padi fermentasi dalam ransum. Sebaliknya kemampuan terrendah dari mikroba dari cairan rumen untuk mendegradasi pakan pada taraf 50\% dan
55\% dedak padi fermentasi dalam ransum.

Secara keseluruhan kecernaan bahan kering ransum berbasis dedak padi fermentasi sampai $60 \%$ sebesar 87,77\%. Kecernaan bahan kering ransum penelitian lebih tinggi dibandingkan dengan hasil penelitian Sulaeman (2001) yang menggunakan pakan fermentasi dengan Aspergillus Niger berpengaruh nyata terhadap kecernaan bahan kering $(87,77 \%$ dibanding dengan $42,01 \%)$. Sama halnya dengan hasil penelitian Ismartoyo dan Budiman (2000) dengan menggunakan mikroorganisme rumen (bakteri, protozoa dan fungi) diperoleh hasil kecernaan bahan kering in vitro $\mathrm{S} 1$ $(25,05 \%), \mathrm{S} 2$ (48,20\%), S3 (30,62\%), S4 $(44,37 \%)$, dan S5 (31,03\%). Ampas pati aren fermentasi dengan menggunakan inokulum Saccharomyces cerevisiae memberikan perbedaan yang tidak nyata $(\mathrm{p}>0,05)$ terhadap kecernaan bahan kering ransum (Anggraeny \& Umiyasih, 2009).

\section{B. Kecernaan Bahan Organik}

Kecernaan bahan organik in vitro menunjukkan proporsi bahan organik yang dicerna oleh enzim kecernaan yang dihasilkan oleh mikroba rumen. Seperti halnya kecernaan bahan kering, kecernaan bahan organik (KcBO) juga dapat dijadikan tolok ukur dalam menilai kualitas ransum. Bahan organik merupakan komponen dari bahan kering sehingga faktor-faktor yang mempengaruhi tinggi rendahnya kecernaan bahan kering akan mempengaruhi tinggi rendahnya kecernaan bahan organik. Penurunan kecernaan bahan kering akan mengakibatkan kecernaan bahan organik menurun atau sebaliknya (Simanjuntak, 2004). Rataan kecernaan bahan organik ransum berbasis dedak padi fermentasi dengan mikroorganisme cairan rumen sapi dapat dilihat pada Gambar 3. 


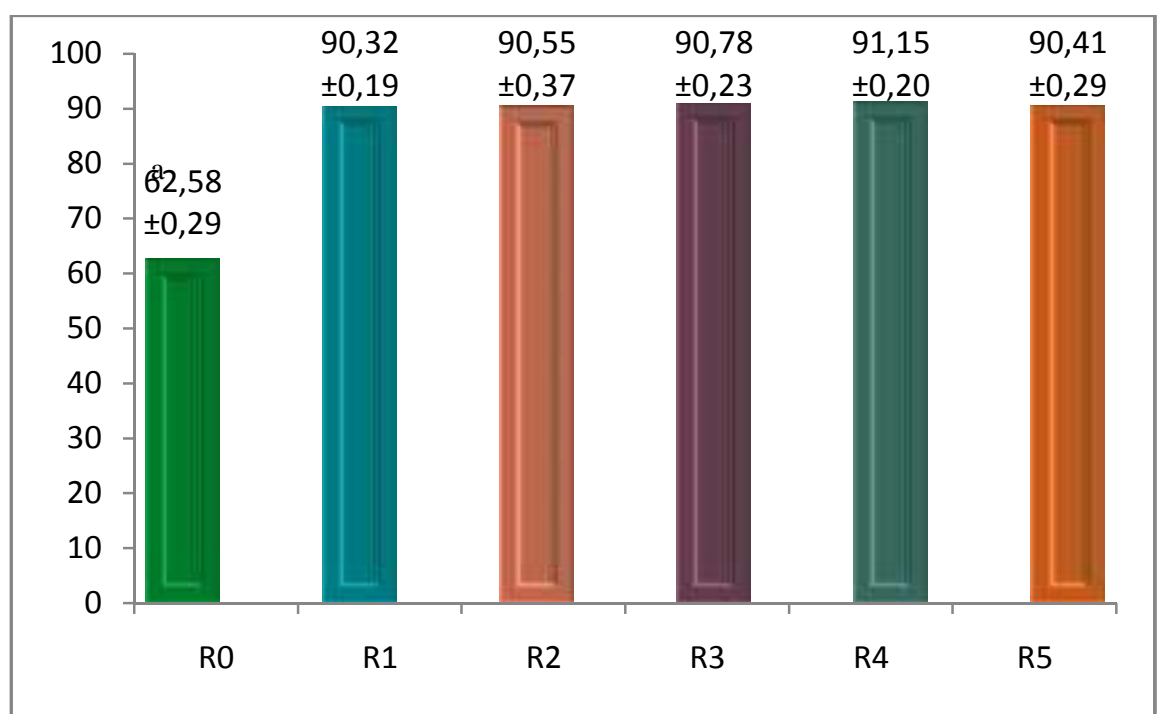

Keterangan; R0= Ransum berbasis pakan non fermentasi, R1= Ransum berbasis dedak padi fermentasi $40 \%$, $\mathrm{R} 2=$ ransum berbasis dedak padi fermentasi $45 \%, \mathrm{R} 3=$ Ransum berbasis dedak padi fermentasi $50 \%$, R4=Ransum berbasis dedak padi fermentasi 55\%, dan R5=Ransum berbasis dedak padi fermentasi $60 \%$.

Gambar 3. Grafik kecernaan bahan organik ransum berbasis dedak padi fermentasi

Hasil analisis data menunjukkan ransum dedak padi fermentasi dengan cairan rumen sapi berpengaruh sangat nyata $(\mathrm{P}<0,01)$ terhadap kecernaan bahan organik ransum. Kecernaan bahan organik ransum pakan non fermentasi $(0 \%)$ lebih rendah dibanding dengan ransum dedak padi fermentasi $40 \%, 45 \%, 50 \%, 55 \%$ dan $60 \%(62,58 \%$ dibanding dengan $90,32 \%$, $90,55 \%, 90,78 \%, 91,15 \%$ dan $90,41 \%$ ). Sebaliknya, kecernaan bahan organik ransum dedak padi fermentasi $55 \%$ lebih tinggi dibanding dengan ransum dedak padi fermentasi $40 \%, 45 \%, 50 \%, 60 \%$ dan $0 \%$ (91,41\% dibanding dengan 90,32\%, $90,55 \%, 90,78 \%, 90,41 \%$ dan $62,58 \%$ ).

Kecernaan bahan kering ransum dedak padi fermentasi $40 \%$ lebih rendah dibanding dengan ransum dedak padi fermentasi $45 \%, 50 \%, 55 \%$ dan $60 \%$ (90,32\% dibanding dengan 90,55\%, 90,78\%, 91,15\% dan 90,41\%). Sama halnya kecernaan bahan kering ransum dedak padi fermentasi $60 \%$ lebih lebih rendah dibanding dengan kecernaan ransum dedak padi fermentasi $45 \%, 50 \%$ dan $55 \% \quad(90,41 \%$ dibanding dengan $90,55 \%, \quad 90,78 \%$ dan 91,15\%). Selanjutnya, kecernaan bahan kering ransum dedak padi fermentasi $45 \%$ lebih rendah dibanding dengan kecernaan ransum dedak padi fermentasi $50 \%$ dan $55 \%$ (90,55\% dibanding dengan 90,78\%, $91,15 \%)$. Sama halnya kecernaan bahan kering ransum dedak padi fermentasi $50 \%$ lebih rendah dibanding dengan ransum dedak padi fermentasi $55 \% \quad(90,78 \%$ dibanding dengan 91,15\%). Hal ini menunjukkan penggunaan ransum berbasis dedak padi fermentasi $40 \%$ dapat meningkatkan kemampuan mikroba rumen untuk mendegradasi pakan.

Rataan kecernaan bahan organik hasil penelitian sebesar $85,96 \%$ lebih tinggi dibandingkan dengan hasil penelitian Anggraeny dan Umiyasih (2009) yang menggunakan ampas pati aren difermentasi dengan Saccharomyces cerevisiae menghasilkan kecernaan bahan organik 38,28\%. Hasil penelitian Sulaeman (2001), Mikroba Pakan Langsung (MPL) dalam ransum berpengaruh nyata $(p<0,05)$ terhadap kecernaan bahan organik $(44,63 \%)$. Kecernaan bahan organik yang tinggi menunjukkan tingginya zat nutrisi yang dicerna terutama yang dicerna oleh mikroba rumen. Semakin tinggi nilai persentase kecernaan bahan pakan berarti semakin baik kualitas bahan pakan tersebut (Andayani, 2010). 


\section{Kecernaan Protein}

Kecernaan protein merupakan kemampuan daya cerna enzim proteolitik yang dihasilkan oleh mikroba rumen terhadap pakan. Kecernaan in vitro protein ditunjukkan oleh konsentrasi amonia dalam rumen (Tasse, 2011). Kisaran amonia untuk pertumbuhan mikroba adalah 3,75 mM$15,00 \mathrm{mM}$ (Satter dan Slyter, 1974).

Kisaran amonia yang mendukung pertumbuhan mikroba rumen adalah 4,00 mM-12,00 mM (Sutardi, 1977). Rataan kecernaan protein ransum berbasis dedak padi fermentasi dengan mikroorganisme cairan rumen sapi yang dihitung berdasarkan konsentrasi amonia $\left(\mathrm{NH}_{3}\right)$ dapat dilihat pada Gambar 4.

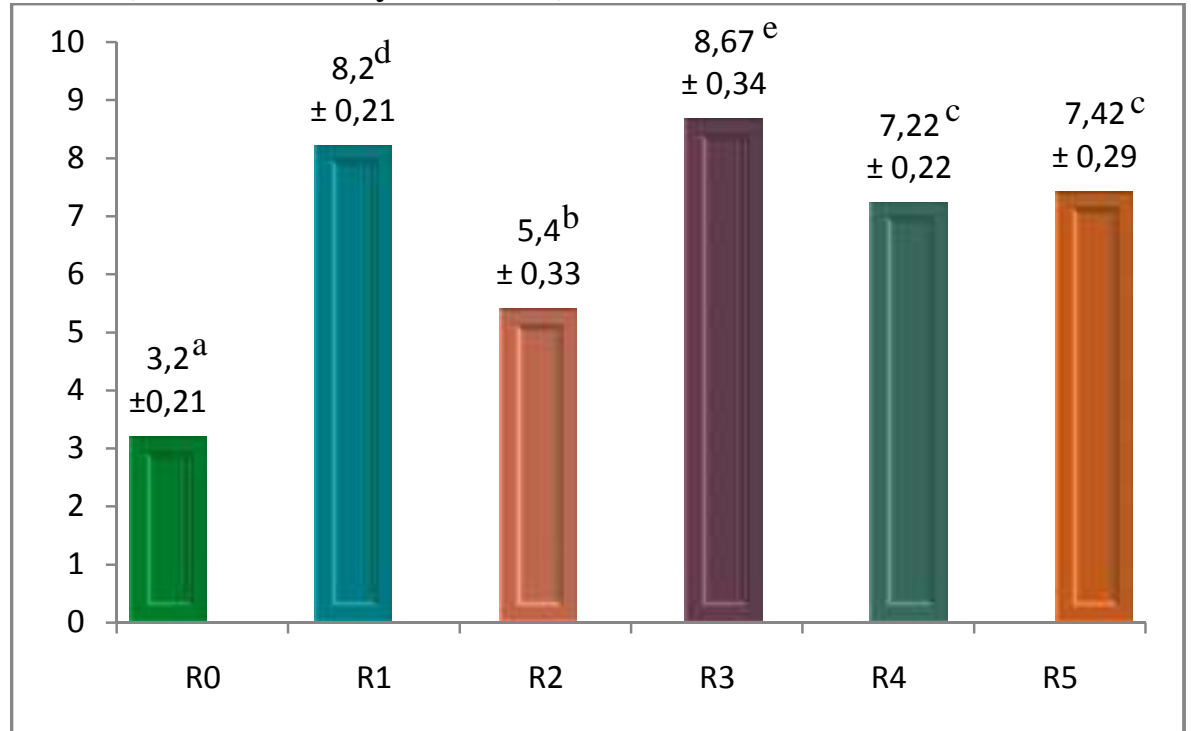

Keterangan; R0= Ransum berbasis pakan non fermentasi, R1= Ransum berbasis dedak padi fermentasi $40 \%$, $\mathrm{R} 2=$ ransum berbasis dedak padi fermentasi $45 \%, \mathrm{R} 3=$ Ransum berbasis dedak padi fermentasi $50 \%$, R4=Ransum berbasis dedak padi fermentasi 55\%, dan R5=Ransum berbasis dedak padi fermentasi $60 \%$.

Gambar 4. Grafik kecernaan protein ransum berbasis dedak padi fermentasi berdasarkan konsentrasi amonia $\left(\mathrm{NH}_{3}\right)$

Hasil analisis data menunjukkan konsentrasi $\mathrm{NH}_{3}$ ransum berbasis dedak padi fermentasi dengan mikroorganisme cairan rumen sapi berpengaruh sangat nyata $(\mathrm{p}<0,01)$ terhadap konsentrasi amonia $\left(\mathrm{NH}_{3}\right)$. Konsentrasi $\mathrm{NH}_{3}$ ransum berbasis dedak padi fermentasi $40 \%$, $45 \%, 50 \%$, 55\% dan $60 \%$ lebih tinggi dibanding dengan ransum berbasis pakan non fermentasi $(0 \%)(8,20 \mathrm{mM}$, 5,40 mM, 8,67 mM, 7,22 $\mathrm{mM}$ dan 7,42 $\mathrm{mM}$ dibanding dengan 3,20 mM). Hal ini menunjukkan penggunaan dedak padi fermentasi $40 \%$ sampai $60 \%$ meningkatkan konsentrasi amonia dan dapat mendukung pertumbuhan mikroba dalam rumen.
Hasil penelitian menunjukkan konsentrasi $\mathrm{NH}_{3}$ ransum berbasis dedak padi fermentasi $50 \%$ paling tinggi mencapai 8,67 mM (Gambar 4). Sebaliknya, konsentrasi amonia terrendah dihasilkan ransum berbasis pakan non fermentasi (0\%). Ransum berbasis dedak padi fermentasi $40 \%$ lebih tinggi dibanding dengan ransum berbasis dedak padi fermentasi $45 \%$, $55 \%$ dan $60 \% \quad(8,2 \mathrm{mM}$ dibanding dengan 5,4 mM, 7,22 mM, dan 7,42 $\mathrm{mM}$ ). Sebaliknya konsentrasi amonia yang dihasilkan ransum berbasis dedak padi fermentasi $40 \%$ lebih rendah dibanding ransum berbasis dedak padi fermentasi $50 \% \quad(8,2 \mathrm{mM}$ dibanding dengan $8,67 \mathrm{mM}$ ). 
Kecernaan ransum berbasis dedak padi fermentasi $45 \%$ lebih rendah dibanding dengan kecernaan ransum berbasis dedak fermentasi 50\%, 55\% dan $60 \%$ (5,4 $\mathrm{mM}$ dibanding dengan 8,67 mM, 7,22 mM, 7,42 $\mathrm{mM}$ ). Selanjutnya konsentrasi amonia yang dihasilkan pada ransum berbasis dedak padi fermentasi $50 \%$ lebih tinggi dibanding dengan konsentrasi amonia ransum berbasis dedak padi fermentasi $55 \%$ dan $60 \% \quad(8,67 \mathrm{mM}$ dibanding dengan 7,22 $\mathrm{mM}$ dan 7,42 $\mathrm{mM}$ ), sedangkan konsentrasi amonia ransum berbasis dedak padi $55 \%$ lebih rendah dibanding dengan ransum berbasis dedak padi fermentasi $60 \%$.

Secara keseluruhan rataan konsentrasi amonia $\left(\mathrm{NH}_{3}\right)$ ransum penelitian sebesar $6,68 \mathrm{mM}$. Hasil ini menunjukkan ransum berbasis dedak padi terfermentasi $40 \%$ hingga $60 \%$ tidak mengganggu pertumbuhan mikroba rumen. Jika ransum defisien protein atau tinggi kandungan protein yang lolos degradasi, maka konsentrasi $\mathrm{N}-\mathrm{NH}_{3}$ rumen akan rendah (lebih rendah dari $50 \mathrm{mg} / 1$ atau $3,57 \mathrm{mM}$ ) dan pertumbuhan organisme rumen akan lambat (Satter \& Slyter, 1974). Menurut Mc Donald et al (2002), jika degradasi protein lebih cepat daripada sintesis protein mikroba maka NH3 akan terakumulasi dan melebihi konsentrasi optimumnya. Kisaran optimum NH3 dalam rumen berkisar antara 85-300 $\mathrm{mg} / \mathrm{l}$ atau 6-21 mM.

\section{KESIMPULAN}

Berdasarkan hasil dan pembahasan disimpulkan bahwa :

1. Ransum berbasis dedak padi fermentasi dengan cairan rumen pada taraf $40 \%, 45 \%$ dan $60 \%$ meningkatkan kecernaan bahan kering ransum,

2. Ransum berbasis dedak padi fermentasi $40 \%$ hingga $60 \%$ meningkatkan kecernaan bahan organik ransum dan konsentrasi amonia $\left(\mathrm{NH}_{3}\right)$. Oleh karena itu, ransum berbasis dedak padi fermentasi layak untuk diberikan pada ternak.

\section{DAFTAR PUSTAKA}

Anggraeny dan Umiyasih., 2009. Pengaruh fermentasi Saccharomyces cerevisiae Terhadap Kandungan Nutrisi dan Kecernaan Ampas Pati Aren. Seminar Nasional Teknologi Peternakan Veteriner. Lokal Penelitian Sapi Potong. Pasuruan.

Anonimous., 2011. Produksi Padi Sultra. Kendari : Badan Pusat Statistik (BPS) Sulawesi Tenggara.

Andayani., 2010. Evaluasi Kecernaan In Vitro Bahan Kering, Bahan Organik Dan Protein Kasar Penggunaan Kulit Buah Jagung Amoniasi Dalam Ransum Ternak Sapi. Fakultas Peternakan Universitas Jambi. Jambi

Hanafiah, K. A., 2008. Rancangan Percobaan. Teori dan Aplikasi. Raja Grafindo Persada. Jakarta.

McDonald, P., R. Edwards, J. Greenhalgh, and C. Morgan., 2002. Animal Nutrition. 6th Edition. Longman Scientific \& Technical, New York.

Satter, L.D. and I.L. Slyter., 1974. Effect of Ammonia Concentration on Rumen Microbial Protein Production In Vitro. Britis. J. Nut. Dalam Imsya. A., 2007. Konsentrasi NAmonia, Kecernaan Bahan Kering dan Kecernaan Bahan Organik Pelepah Sawit Hasil Amoniasi secara In Vitro. Fakultas Pertanian Universitas Sriwijaya, Kampus Indralaya Km 32, Ogan Ilir Palembang. 
Simanjuntak. C.M., 2004. Karakteristik

Zn-Organik dan Pengaruh

Suplementasinya terhadap

Kecernaan Pakan Serat (In

vitro)http://repository.ipb.ac.id/h

andle/123456789/8188

$(25$

maret 2012)

Sulaeman., 2001. Produksi Mikroba

Pakan Langsung (MPL) dari

Kapang dan Pengaruhnya

terhadap Aktivitas Fermentasi

dan Kecernaan Ransum

Ruminansia (In Vitro).Institut

Pertanian Bogor. Bogor

Sutardi, T., 1977, Ikhtisar Ruminologi.

Bahan Penataran Khusus

Peternakan Sapi Perah di Kayu

Ambon. Lembang. BPLPP.

Direktorat Jenderal Peternakan,

Bandung

Tasse A. M., 2011.Campuran Garam

Karboksilat dan Metil Ester

Kering sebagai Suplemen Asam

Lemak Omega 3. Masagena

Press, Makassar.

Widayanti dan Widalestari., 1996.

.Limbah untuk Pakan Ternak.

Trubus Agrisarana. Surabaya. 